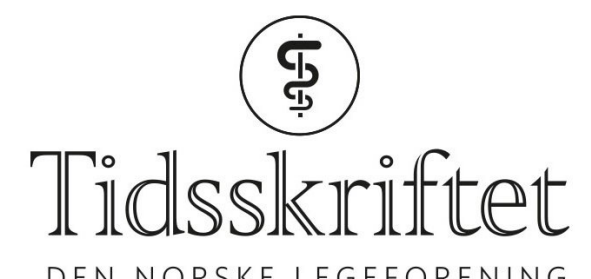

DEN NORSKE LEGEFORENING

\title{
Didaktisk om laparoskopisk lever- og pancreaskirurgi
}

ANMELDELSER

\section{KJETIL SØREIDE}

Overlege, Gastrokirurgisk avdeling Stavanger universitetssjukehus

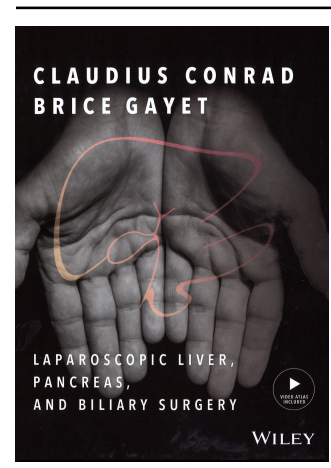

Claudius Conrad, Brice Gayetred.

Laparoscopic liver, pancreas, and biliary surgery

482 s, tab, ill. Chichester: Wiley-Blackwell, 2017. Pris GBP 135

ISBN 978-1-118-78117-3

Målgruppen er alle som er interessert i og vil fordype seg i minimal invasiv kirurgi på lever, pancreas og galleveier. Selv om målgruppen beskrives å være generelle kirurger så vel som transplantasjonskirurger, i tillegg til dem som driver med kirurgisk onkologi, er i hovedsak innholdet rettet mot kirurger og sentre som driver med større lever-, galleveis- og pancreaskirurgi (HPB-kirurgi). For eksempel er ikke vanlig laparoskopisk kolecystektomi med som prosedyre, og lite eller ingenting omtalt i teksten rundt benigne tilstander.

Boken består av to deler: tekstbok og videoatlas. I tekstdelen, som består av 24 kapitler, omtales alt fra den historiske utviklingen innen minimal invasiv kirurgi, til en rekke generelle temaer, som utredning, staging, betydning av intervensjonsradiologi og medisinsk onkologisk behandling av lever og pankreas neoplasier. I egne avsnitt omtaler man mer lever-og pancreasspesifikke temaer, inkludert anatomiske aspekter. Spesielt sistnevnte er rikt illustrert med flotte tegninger og diagrammer.

Del to, videoatlaset, består av 26 kapitler, med kort tekst og stillbilder. Hvert kapittel er ment å ledsage en medfølgende video. Videoatlaset er tilgjengelig på nett og kan ikke lastes ned. Disse videosnuttene er 10 til 20 minutters didaktiske presentasjoner av enkelte hovedelementer i hver prosedyre - som er et kjapt sammendrag av tidkrevende prosedyrer. 
Videoatlaset er delt inn i enkle og komplekse leverreseksjoner, hvor også miltkirurgi er omtalt under pancreaskirurgi. Enkeltkapitler står tematisk alene, som "living donor left lateral sectionectomi” som eneste transplantasjonstema, og "cystgastrostomy” for pancreas pseudocyste uten at dette er drøftet i teksten.

Videoatlaset representerer kanskje det beste innholdet i denne boken, men det krever nettilgang. Andre bøker har nedlastbare moduler som kan ses offline med en tilgangskode.

Det onkologisk kirurgiske aspektet dominerer, og innhold som er rettet mot transplantasjonskirurger er sparsomt.

Forfatterne er eksperter innen sine områder og kommer fra Asia, Europa og USA. Claudius Conrad jobber ved MD Anderson Cancer Center i Houston, og flere av forfatterne er fra samme institusjon. Franskmannen Bruce Gayet tør være kjent for de fleste som er interessert i laparoskopi, og han er sannsynligvis den som har gjort nær de fleste av prosedyrene i videoene, uten at dette er angitt. For- og etterord er skrevet av flere ledende lever- og pancreaskirurger, både med lovord og ettertanker rundt betydningen av minimal invasiv kirurgi for komplekse HPB-tilstander.

Som en didaktisk presentasjon lykkes forfatterne i stor grad innen avansert laparoskopisk HPB-kirurgi, men boken er mindre generell enn hva tittelen skulle tilsi.

Publisert: 4. september 2017. Tidsskr Nor Legeforen. DOI: 10.4045/tidsskr.17.0399

(C) Tidsskrift for Den norske legeforening 2020. Lastet ned fra tidsskriftet.no 